\title{
States, Nations, and Civilizations
}

\author{
Göran Therborn ${ }^{1}$ (1)
}

Received: 28 September 2020 / Accepted: 14 October 2020 / Published online: 28 October 2020

(c) The Author(s) 2020

\begin{abstract}
Nation-states are inherently part of cultural formations, sustaining, legitimating, and inspiring them. The nations sustaining contemporary states are very different, and major routes of historical nation-state formation can be distinguished, which means that global discussions of nation-states cannot be confined to such states "in a European sense" only. Civilization(s) is a concept with different meanings in singular and in plural, belonging to different semantic fields, at least in European languages. As a singular concept it arose in mid-eighteenth century, distinguishing a high degree of social and cultural development from "barbarism" and "savagery". It spread rapidly across European languages in the nineteenth century with European world supremacy and evolutionism, as a European self-designation. Civilizations in plural first appeared on a large intellectual scale after World War I, the horrendous slaughters of which shattered the Western ideas of continuous evolution and progress, and of the West as the unique pinnacle of human development. In the plural, civilizations have been used in philosophies of comparative history and evolution, but it may also be used as a tool of cultural analysis. In this sense, civilizations refer to large, ancient enduring cultural configurations, to the deepest layer of contemporary cultural geology. In terms of current demographic size five major such civilizations can be identified. They impinge upon the political culture of states, upon the visions and the language of the state rulers. They do not clash, and they do not determine state behaviour. Nations and civilizations are compared as cultural entities or referents, with a view to laying a basis for analytical comparisons of nation states and civilization-states, in particular their implications of agency, time and history, including their different historical contexts of emergence. The nation and civilization designations of states also related to a wider range of contemporary state categorizations. Contemporary politics and political theorizing of civilizations are looked at in brief empirical overviews of the impact of civilizations upon international relations in the wake of Samuel Huntington's thesis of "clashes of civilizations", and of the promise of civilization states as a political project, and as an illuminating tool of cognition.
\end{abstract}

Göran Therborn

gt274@cam.ac.uk

1 University of Cambridge, Cambridge, UK 
Keywords Nation $\cdot$ Civilization(s) $\cdot$ Nation-states $\cdot$ Civilization states $\cdot$ Modernity

Civilization(al)-states have recently and suddenly become a central phenomenon of international politics. Civilizations were thrust into the arena of international relations in the 1990s by the US political scientist Huntington $(1993,1996)$ predicting a post-Cold War world as a "clash of civilizations". "Civilization-state" was launched as a concept by the British journalist and independent scholar Jacques (2009) as a characterization of China, referring primarily to its uniquely long continuity as a political entity. Jacques' brief but crucial designation was taken up and elaborated with gusto by the Chinese scholar Zhang (2012). Civilizational analysis entered the field of international relations in a broader sense than Huntington's "clashes" with a volume edited by another distinguished US political scientist, Katzenstein (2010). By 2019, "the rise of the civilizational state" has become a hot topic of scholarly and political debate (Coker 2019; Prakash 2016; Rachman 2019; Acharya 2020; Macães 2020; Roussinos 2020).

To call a state civilizational or a civilization-state is to give culture a primacy in understanding it. It is also a way of distinguishing it from nation-states, although a nation is a cultural entity or referent too. Now that the range of concept has widened, from a Chinese particularity to a type of states which are even contemplated as possibly overtaking nation-states, becoming the typical state of the twenty-first century, at least of large ones, a clarification of the meaning of a nation-state and its differences and eventual similarities with its new conceptual challenger is needed.

The nation is a pivot from which the many issues related to controversies around "culturalizing the state" and "civilizational states" can be approached. All modern states are nation-states, claiming to represent, to embody one nation, or more, as binational or multinational states. Canada is an example of the former, Bolivia and South Africa exemplify the latter. The world still contains a few non-national states, the most significant are the autocratic dynastic monarchies of the Arab peninsula non-modern states according to most general conceptions of political modernity. Culture is intrinsic to the concept of nation, although national cultures vary not only in their content, but also in their constitutive principles of construction. A nation-state is therefore always "culturalized" in some ways.

A modern state without a national cultural identity is conceivable, and has actually been conceived, without much practical success though. The idea of "constitution patriotism" (Verfassungspatriotismus) was launched in West Germany in 1979 by the political scientist Dolf Sternberger and taken up in the 1980s by the great West German philosopher Jürgen Habermas. German nationalism had been utterly discredited by the atrocities of Nazism, and Germany was divided into two. In the eyes of many Germans, there was not much German to be proud about. In international surveys from 1970 to 1990, West German national pride was the lowest in the world, and domestically clearly a minority phenomenon (sources in Therborn 1995, p. 280). The only legitimate patriotism, then, according to Sternberger and Habermas was attachment to the "libertarian-democratic" 
(freiheitlich.demokratisch) constitutional order. This "thin-blooded even though well-meaning professorial fiction" (H.-P. Schwarz) never got much traction, and faded away with the rejuvenated Germanismus of reunified Germany (Schölderle 2011) In several European countries, including Sweden, practices of national rituals and symbolism have increased in frequency in this century.

\section{Nations and Their States}

Nation refers to a collectivity of people, born or living in the same place or territory. As such it emerged as a medieval European concept, used, for example, to group and accommodate university students or Christian Church Council delegations from different parts of Europe. Later on it acquired a political meaning, comprising the collectivity of the institutionalized elites of a realm, basically the nobility and the high clergy, the "lords and the bishops" as Montesquieu defined the nation in mid-eighteenth century (Schulze 1994, p. 117). With the French Revolution, that definition was turned upside down. The "complete" nation was the ordinary people, without the privileged orders (Nora 1988, p. 803). That was the revolutionary version of the modern meaning of nation, as a political collectivity of people.

The rise of nations in the modern sense was due to the erosion and successful challenge of heteronomy, of a profound divide between rulers and ruled. A nation is a population with a collective identity and with a collective claim to some kind of self-rule, not necessarily a sovereign state of its own. Inherent in this collective identity is a common culture of meaning. A nation-state is a representative of this common culture and the national claim to self-rule. The late 18th-early nineteenth century Atlantic revolutions of France and the Americas saw the breakthrough of nation-states. Nation-state making became a central political preoccupation of nineteenth century Europe, finally successful with the breakdown in World War I defeats of the dynastic empires of the Habsburgs, the Hohenzollerns, the Ottomans, and the Romanovs.

A common culture does not have an intrinsic primacy in nation-states, indeed its position is a major variable among nations. However, it has an intrinsic presence, nations have cultures and the legitimacy and the cohesion of nation-states are dependent on national cultural identities among their citizens, and all nation-states devote considerable efforts at inculcating and cultivating them, with symbols, rituals, rhetoric, and curricula.

Nation-states have arrived along very different paths, with very different cultural baggage. We may distinguish four major pathways, along which the cultural formation of nations was moulded. Culture had a different meaning and importance in these types of nation-state formation.

First, there is the pioneering European route, centred around Nation-Prince relations, a route along which a coalescing nation asserted itself against the dynastic realm of the Prince, by violent revolutionary rupture or by gradual negotiation. The emerging European nation-state developed out of the internal contradictions and conflicts of European societies - although these were often impacted by imperialist wars overseas-, laying the foundations of the characteristic combination of 
(relative) cultural unification and class division of the new states. The post-dynastic nation-states of Europe were strongly anchored in popular and territorial history, distinguished from the shifting extensions of the landed property of princely power, a history with a rich congruent cultural heritage, though differentiated by dialects and local customs. The creation and imposition of a unified national language, by dialect selection and by grammatical and orthographic codification became a major task of many European nation-states (See, e.g. Weber 1976). Where possible, minority languages were driven out of national culture.

The typical European nation-state emerged out of internal conflicts of a dynastic state, and class is first of all an intra-state division. The pioneered Industrial Revolution provided the political division with a strong socio-economic foundation. As the established churches almost everywhere-except in Ireland and Poland-sided with the monarchy and the aristocracy, Europe gradually became the world's most secularized continent.

Secondly, there are the settler states, the socio-political outcomes of the overseas European conquests and settlements in the early modern period: the Americas, White Oceania, South Africa. Nation-states emerged here as political secessions from the colonizing motherland. These nations have little cultural heritage of their own, sharing their language, their religion, and most of their history with the divorced motherland. The distinctive culture of their nation-state formation is that of the universalistic European Enlightenment, together with Christianity and a resurrection of ancient Greco-Roman republicanism, which they are claiming against their motherlands' denial, betrayal, or corruption of Enlightenment values. The claim to represent a universalist Enlightenment and Ancient Republic politics is strongest in USA, where it is reinforced by the millenarian New World ambitions of Puritan Protestant Christianity. From the very beginning, USA is not just the state of the former Thirteen North American Colonies of Britain but the No. 1 state of freedom and equality in the world. (Commager 1950; Wood 1971; Lepore 2018).

In Latin America, with a thin proto-national culture left after almost two decades of Independence wars, it was unclear what the nation was to be. The Liberator-Hero Simon Bolívar led a successful rebellion in Venezuela, and became later President of Bolivia, of Peru, and of Gran Colombia. Nation-concepts from colonial administrative units at varying level competed with Panamericanism of variable dimensions. The former finally won out (Annino and Guerra 2003).

All the settler countries define their nation as a club, which people are encouraged to join-provided they have the proper criteria. But the clubs are exclusive. The Natives of the country were excluded from membership in the US, Canada, Australia, and gradually also South Africa. In Latin America they were mostly too many and too strong to be denied entry of the new state on their own land, so also in New Zealand. Slaves and freed descendants of slaves were generally excluded from participation in the new states of the Americas. Desired immigrant members were White Europeans, preferably Northern Europeans. Targeted immigration from Europe was a major dimension of nation formation. Others might occasionally be allowed in, for hard work, but without membership. The Supreme Court of California motivated this 1854 by declaring Chinese as "a race of people whom nature has marked as inferior, and who are incapable of progress..." (Lepore 2018, p. 325). 
Racism and racial division are intrinsic part of settler culture and settler societies, reflecting and legitimating the conquests and expropriations by the settlers and slaveholders. As the Black Lives Matter movement and the lethal police shootings of Black men in the summer of 2020, racism is still endemic to at least a part of the American state.

A third pathway of nation-state formation went through the vast Colonial Zone, stretching from northwestern Africa to Papua New Guinea, lands conquered and ruled but not stably settled by colonial powers coming from far away. The anticolonial movements here learnt their notions of nation, self-determination, human rights, and development from their colonial masters, applying the ideas to their own situation, and turning them against their rulers. The colonized peoples usually comprised several ethnic groups, each with its own culture, language, history, and of different religious beliefs. The only basis for a national culture was the experience of colonial rule, the national borders the result of colonial carve-ups. What came out of this was a particular kind of nation-state, with diverse and fractured indigenous societal agglomerations contained in post-colonial states, governed in the language and according to juridico-administrative procedures of the former colonial power by a political elite with colonial-size privileges.-Post-apartheid South Africa has changed from a particularly racist settler state into a rather common post-colonial country.

Finally, there is a course to political modernity without directly establishing a nation-state, which we may designate as Reactive Modernization. The designation refers to polities seriously threatened but never fully subjugated by alien imperialism; polities which managed to survive into the modern world by adopting modern state institutions from abroad and grafting them on to indigenous rule and a moulded indigenous society. Modernization, including modern citizenship rights (but not democracy), in this case came from above, from rulers in power rather than from popular struggles. Modern instrumental reason of statecraft, technology, and economics was selectively imported and fitted together with a relatively unified, evolving but basically preserved indigenous society and its culture. Japan of the Meiji Restoration is the grand historical case of a successful non-European trajectory through modernity by Reactive Modernization. Below we shall look into how the outcome of the Meiji Ishin relates to the concept of a civilization state. Siam did also pass, although at a more modest level, while attempts by the late empires of the Qing and the Ottomans failed. (On enduring effects of these different kinds of nation-state formation, see Therborn 2011).

\section{Civilizations and States}

Civilization, derives from Latin civitas, city, and has a different meaning in singular and in plural. As a singular it became a concept in French in the mid-eighteenth century, distinguishing a high degree of social and cultural development from "barbarism" and "savagery". It spread rapidly across European languages and became an important part of the nineteenth century evolutionist conception of history (Bowden 2016). However, since 1919 it is mainly used in plural, particularly in scholarly 
contexts, in comparative studies of world history (Braudel 1987, p. 41ff). In aggressive political rhetoric it continues to be used in singular.

The moment of nations and nation-states, we noticed above, was the breakdown of heteronomy of peoples, by dynastic states, closed urban oligarchies, tribal elders and chiefs. Civilization in singular arose with European world supremacy and evolutionism, as a European self-designation. Civilizations in plural first appeared on a large intellectual scale after World War I, the horrendous slaughters of which shattered the Western idea of continuous evolution and progress. Between the two World Wars and just after a number of ambitious and much-debated works on civilizations appeared, from Spengler's The Decline of the West (1918-22/1991) to Arnold Toynbee's A Study of History (1934-61) A main focus here was the historical development and, especially, the decline of civilizations. In the 1990s Huntington added a vista of coming inter-civilizational conflicts.

There is no consensus on what civilizations in plural are, how they should be defined, and how many of them there are. But Huntington (1996, p. 43) provides a fruitful starting-point for different specifications: "A civilization is the broadest cultural entity". He goes on to say that it is the broadest level of identification, the biggest entity within which people "feel culturally at home". Taking an agnostic position on identification in this context, I have found the concept useful for analysing the cultural geology of societies, by designating large ancient cultural configurations with an enduring cultural impact (Therborn 2011, ch. 1).

\section{The Five Largest Civilizations of the World}

By civilizations I am referring to enduring ancient, large-scale, territorial cultural formations, transcending political regimes in space and time. The cultural configuration developed embedded in characteristic trans-ethnical affinities of economic and social practices developed in interaction with the natural environment which the population had to adjust to. The cultures of civilizations have three main components.

First, a foundational culture, a cosmology, a view of the world, of its origin, its meanings, and its destination, a conception of the supernatural and a location and identification of the divine. Religion is usually a central part of a civilization, but not necessarily its core, as the Sinic East Asian example shows.

Secondly a pattern of social relations, embodied in institutions of family, kinship, and practices of livelihood in coping with a given environment, shaped by the natural ecology of the cultural formation. For example, the temperate lands of mixed agriculture in Europe, close to water and navigation, with long, winding coastlands and navigable rivers. The desert-cum-oases ecology of Arabo-Islamic civilization of nomadic pastoralist Bedouins and urban merchants. The vast labour-scarce, interrelated tropical and savannah lands of Africa, with limited riverine navigability and largely off the Eurasian trade routes of cultural exchange, sticking to hoe agriculture and non-literary at its core, despite the Ethiopian Church and the Muslim Timbuktu library. The Sinic civilization, the only continuous and enduring riverine early high culture civilization, encompassing the continental land mass of China as well as 
spreading to the Korean peninsula, the Japanese islands, and southwards to northern Vietnam, areas with an affinity of wet-rice agriculture. The large and ancient Indic civilization has a more discontinuous history with the disappearance of the original Indus valley culture, while remaining a river plain socio-cultural formation-its territorial base is the large agricultural territory of the Indian sub-continent, since ancient times connected to China in the East and to West Asia and Europe in the West.

Thirdly, a historically developed guiding tradition. Literary civilizations define what is the "classic" canon and a "classical education", of language, literature, art, architecture, thought. A common tradition of a non-literary civilization, such as the African, can be expressed through orally transmitted tradition in interlocking chains of myths, artistic expressions, like dance and masks, and even housing. In my interpretation, civilizations constitute the deepest layer of the cultural geology upon which our current cultures are built. An implication of this perspective is that we are formed also, and often more importantly, by other, more recent cultural strata. One example is the historical pathway to modernity, expressed inter alia in the different routes to a nation-state, which we touched upon above.

The five largest civilizations today are, the Sinic civilization, originated in and centred on China, but also including Korea, Japan, and (northern) Vietnam, with a common high culture of Chinese script and a Chinese classical canon, including Confucian philosophy.

The Indic with its Sanskrit language, comprising South Asia, with extensions into contemporary Indonesia, Cambodia, Thailand, and Myanmar, which three latter countries derive their script from India, and whose state ceremonies still derive in part from Indic culture, including the official name of Thai kings, Rama.

The West Asian Arab-Muslim configuration of West Asia and North Africa, reinforced by Persian imperial court culture and conceptions of political power, reaching out to Central and South Asia, with the Timurids and the Mughals. A civilization connected not only by the Islamic faith and tradition, but also by a High Arabic language, above the national vernaculars, and before the European intrusion by secular Persian language, architecture, and culture.

The European Greco-Roman cum Christian civilization-its two traditions successfully married by the early medieval Church-and its overseas offshoots, in the Americas and in Oceania. The university curriculum of Classics include the languages of Latin and ancient Greek, and the literature and history of Greco-Roman Antiquity, from which "classical" European architecture also derives.

Finally, the Sub-Saharan African, the only non-literary civilization and therefore without "classics" or canon, but nevertheless a complex unity of its own, sustained by large-scale population mobility, of spiritual-mythical and artistic affinities, of linguistic kinship, of similar land-labour relations and forms of agriculture.

The five largest civilization by population are all among Huntington's (long) list of nine, and the four he adds are all smaller, the (Christian) Orthodox, the Latin American, the Buddhist, and the Japanese.

Each civilization contains at least traditions of political rule, and often explicit, more or less elaborate principles of government. To what extent they are relevant today varies and is open to debate. The Sinic civilization has a unique continuity, 
embodied in a core state, China with a millennial imperial institution-now broken, though only since 1911—, and in revived ancient social philosophy, Confucianism. African civilization was basically stateless, and its tribal traditions of authority and identity are still alive. Despite recent attempts at linguistic and cultural re-Sanskritization, Indic civilization has a fragile continuity, its central religious component was once Buddhism, now replaced by Hinduism. It was never based on a central core state, and its Hindu-Buddhist conceptions of ritual kingship are currently politically marginal, though recently controversial (Thailand), or irrelevant (India). The imperial Persian implant on West Asian Islamic civilization has fallen by the colonial wayside, and the attempt to revive the more orthodox Islamic Caliphate has been disastrous. The European civilization included institutions of deciding and voting assemblies, from the Athenian Assembly of citizens and the Roman Senate, traditions carried through into the second millennium C.E. by the Christian Church Councils and by the election of the two highest positions of medieval Europe, the Pope and the Emperor (of the Holy Roman Empire of German Nation). North of Greco-Roman Antiquity there were Germanic peasant assemblies-cum-courts and elected kings. However the civilization splintered politically into warring states rules by Absolutist dynastic monarchs, and has later mutated culturally, into a transAtlantic Western, increasingly secular configuration.

Every civilization has had its periods of expansion, as well as of contraction. However, they differ whether they have an inner drive to ruling the world or not. There are missionary and non-missionary civilizations. The Arab-Islamic and the Euro-Christian civilizations are missionary, of world salvation, the civilizations of jihad and crusades. The three others are not. The Islamic mission is exclusively religious, divine sharia law is its main political mission. Euro-Christian or Western civilization, on the other hand, has largely secularized its mission into liberalismcum-capitalism, also traded under the label of liberal democracy.

\section{The Political Moment of Civilizations}

Above I argued that the political moment of nations and nation-states was the erosion of and challenge to the heteronomy of peoples by dynastic states and other forms of autocracy. What is then the political moment of civilizations, in plural? The moment of civilization politics and international relations arrived with the unexpected erosion of and challenge to universalistic conceptions of states and politics. Previously in the twentieth century, states were distinguished in universalistic political or socio-economic terms, as democracies and dictatorships, as socialist and capitalist states, as liberal democracies and popular democracies, as belonging to the "Free World", to the "Socialist Camp" or to the "Non-Aligned Movement" of the Third World. By 1991, it seemed that "liberal democracy" had vanquished the world, and ended history (Fukuyama 1992) However, what happened was that once one of the universalistic conceptions appeared to have won over all the others, a series of particularistic challenges emerged. Huntington $(1993,1996)$ was not alone and perhaps not the first to see this shift (Huntington 1996, p. 324n. 18), but he has been the author with the main impact, in articulating and elaborating it. 
After 1991, and the dissolution of the Soviet Union, there is no politically important universalist challenge to capitalist democracy - the only such challenge, fundamentalist Islamism, emerging as a force after its Saudi-US financed anti-Communist victory in Afghanistan, has not been without significance but never near an alternative of global importance. However, liberal democracy could not establish a peaceful world order, sitting as it was on top of a welter of seismic waves produced by past streams of violence, exploitation, and domination. Liberal democracy was unable to cope with the outbreaks of pent-up anger and resentment in any liberal or democratic way, almost destroying Russia and ex-Yugoslavia, and creating an arc of aerial slaughter and destruction from Afghanistan to Libya. At the same time it was largely losing its democratic credentials at home through increasingly obvious and scholarly documented plutocratic rule (see further Therborn 2020). In this democratic vacuum various particularistic cultural conceptions of politics are emerging. The civilizational state is one of them, the most ambitious.

The new angle of the 2010s, is that civilizational states has come to the fore as a reflection of a challenge to liberal-democratic superiority by the meteoric rise of China in prosperity and power. The contrast to the outcome of the restoration of capitalism in Russia under Western liberal-democratic imposition-including import of Thatcher's election managers from Britain-is stunning. Russia's national income per adult fell from two thirds of the Western European in 1975 to less than forty per cent of it in the 1990s, about the same level as in the mid-1920s or in 1870. By 2000 the richest ten per cent appropriated more than half the national income, ten percentage points higher than in 1905 under the Czars (Alvaredo 2018, figs. 2.8.2, 2.8.3).

For a serious political debate-scholarly, intellectual, and civic_-a questioning of actually existing liberal democracy should be welcome. Particularly since the latter is now in many parts of the world very different from the rule of the people which the historical democratic movements had in mind and fought hard for (cf. Therborn 2020). Actually existing liberal democracies may be governments of the people, but hardly by the people or for the people. However, the meaning and implications of civilization states in relation to the prevailing modern pattern of nation-states have to be clarified before a fruitful debate.

\section{Nations and Civilizations}

Nations and civilizations are both cultural concepts, so what are the differences between nation-states — of which there several very different kinds-civilizationstates? Most nation-states of the world are not, as we saw above, the "coherent cultural complexes", which Katzenstein (2010, p. 5) thinks they are. Jacques (2009) has said that "China is not a nation-state in the European sense of the term", agreed, but neither is India, Nigeria, USA, and most of non-European states. Jacques' analysis of the singularity of China is in many ways eye-opening, and has been acknowledged by Chinese scholars as insightful, to the extent of being elaborated upon (Zhang 2012). However, the civilization-state has become a general concept of contemporary political science and rhetoric, which takes the discussion, and needed clarifications, beyond China. 
Nation-states and civilization-states are both political inventions, and both are used as tools of political rhetoric. As such, civilization is a heavier hammer in rhetorical combats, with higher requirements of age and, in particular, size. Nationstates are always younger, because they all belong to the future-oriented epoch of modernity, despite their frequent historical myths of their nation, whereas the gravitas of a civilization derives from its ancientness, i.e. its pre-modernity Size means, for instance, that Sweden can claim to be a nation-state, but not a civilization-state, which is an option to Russia. State rhetoric more often than not uses civilization as something larger and deeper than state culture, in their claims to represent and to defend "Western civilization", "Christian civilization", "Asian civilization". It certainly sounds more solemn and lofty than, say, Apartheid civilization, Zionist civilization, Hungarian or Singaporean civilization.

Thirdly, the boundaries of civilization are usually more blurred than those of nations, which might create problems for self-proclaiming civilizational states. Professor Bai (2020, p. 207) has pointed to the problematic of Chinese state territories with Uighur and Tibetan populations inherited from Qing dynasty conquests but not integrated into Chinese civilization. On the other hand, civilizational fuzziness may also be used for making claims to regional hegemony, as in a Turkish nationalist self-designation of Turkey as a civilizational state, "Such a state aims to create a regional space ... (through) strong cultural and social bonds with other people of the region." (Al-Hafidh 2020) Or for overriding state boundaries of citizenship, in claims to allegiance by a national diaspora, and in privileges of immigrant citizenship to fellows of the same civilization, be they European in 19th-early twentieth century Americas or Hindus from neighbouring countries as in contemporary India.

Agency is an important difference between nations and civilizations. Nations act, or can at least be imagined as acting. Civilizations mould actors, and they may "clash", in the sense worldviews or values collide, but civilizations do not act. Nations and civilizations are both "imagined communities", but a nation is an acting community and a civilization is a community of values, worldviews, and practices. Huntington's (1996, p. 207ff) clashes of civilizations or "intercivilizational conflicts" are actually either conflicts between neighbouring states or groups belonging to different civilizations or between "core states" of civilizations.

Time and history also differentiate nations and civilizations. As cultural complexes both are, of course, situated in history and flowing with time. This moving situatedness in time was actually the main focus of the original historiography of civilizations in plural, by Spengler, Toynbee and others. However, the current recourse to civilization as a foundation and as a distinguishing characterization of states tend to use the concept as a timeless essence without history. National cultures, by contrast, are full of historical events of the nation, of defeats as well as of victories, of subjugation as well as of glory, of villainous as well as of heroic and magnificent actors.

Together, agency and historicity probably best highlight and distinguish nations and civilizations, nation-states and civilizational states. Nations are actors and the political rise of nations, the constitution of nation-states were historical events, of fundamental political change. The sovereignty of the nation replaced, by negotiation and reform or by rupture and revolution, the sovereignty of the 
dynasty, the lineage, or the sword. National sovereignty meant, inter alia, that the nation claimed the right to build a new future, unhampered by inherited traditions. Because of this future orientation, the constitution of nation-states marks the arrival of political modernity. By contrast, the recent declarations of civilizational states mean an invocation of an ancient past. It also entails attempts at erasing the modern history of the country, such as in China and Russia the toppling of the dynastic empires of the Qing and the Romanovs, and the deep socioeconomic transformations by the USSR and the PRC.

The rise of nations and nation-states was a revolt against the prevailing "elites", the dynastic families, the imperial bureaucracies, the aristocracy, the high clergy, the big landowners, the big merchants and factory owners. Civilizations, are, above all and particularly in their inherited and currently invoked form, crystallizations of elite culture. In current Chinese discussion (e.g. Zhang 2012; Bai 2020; Bell and Pei 2020) argumentation for rule by meritocratic elites is central. Without here entering into a debate of democratic popular rule versus meritocratic elite rule, I will make three comments problematizing meritocracy.

First the question, Whose merits? Meritocracy in ancient Chinese civilization had a quite limited range. The emperors and the dynasties were not recruited by selection of talents by merit. Kinship and inheritance of land patterned wealth and power. Female talent was never asked for, although a few women in the dynastic complex could manoeuvre for influence. Those, and other limitations, were only swept away by the modern revolutions.

What merits? Was classical literary knowledge and skills good merits for governing a country in a period of industrial technology and industrialized warfare? Modern critics of China's ancient tradition did not think so. There is knowledge from books, and there is knowledge from experience, and for providing welfare for the population, knowledge from the bottom of society is as necessary as knowledge out of the fortunate life experiences of the elites, arguably more necessary. These and similar considerations delegitimized the merits of the mandarin elites. The general problematic of the vast range of knowledge necessary for a society to function well still holds. The brightest computer scientist is not necessarily the best person to run a city.

Thirdly, there is a question of the merits of generations. Meritocracy is what liberals call equality of opportunity. Usually lost in the argument is that the opportunities and the merits of one generation are largely shaped by the inequalities of the parental and still earlier generation. In the United States this is now being noticed because of the enormous investments in their children which upper and upper middle class parents are making, from exclusive pre-schools, exclusive private schools, preparations for elite universities, to expensive elite higher education (Markovits 2019). Inter-generational mobility in contemporary China has declined for the cohorts born after 1970, both with respect to income and to education, i.e. parental income and education is influencing more strongly the income and education of their adult children (Fan et al. 2015). In international comparison, the correlation between the relative) income of parents and children appears very high, whereas the education connection is rather low, probably largely due to the disruption of the Cultural Revolution (Gong et al. 2012). 
Once functioning elites may lose touch or function with social evolution. The history of nation-states includes what I have called Popular Moments, most often peaceful, crucial events of national agency, when a prevailing national elite is widened or replaced by rising popular forces, e.g. the workingclass in Europe, excluded ethnic groups in the settler states, other nationalist movements in ex-colonial countries, lower castes in India (Therborn 2017, ch.6).

\section{The Politics of Civilizations}

The politics of civilizations entered the world because of the way the Cold War ended. The victor was liberal democratic capitalism, but the victory was not. Politically, capitalism was nowhere a winner, the Eastern European anti-Communists studiously avoided demonstrations for it, and socialist values remained majoritarian, even in East Germany, well after the implosion of Communism (Therborn 2020). The Soviet Union was fought to a very costly stalemate in Afghanistan, not by liberal democrats, but by fundamentalist Islamists, financed and armed by Saudi Arabia and USA. The break-up of the USSR and of Yugoslavia-including multicultural Bosnia-Hercegovina, whose civil war provided an important bridge of fundamentalist Islamism from Afghan reaction into a global strike force-was not efforts to establish liberal democratic capitalism, but political entrepreneurship promoting ethnic nation-states.

Liberal democratic capitalism is a thin identity, and intrinsically self-contradictory as capitalism is antagonistic to democracy, and usually illiberal in its rule of enterprises. Despite its victor status, it could not cope hegemonically—only by dominant power-with the inequalities, resentments, and conflicts of interest in the world. The alternative of "Western civilization" as a singular pinnacle of human development had already lost most of its appeal in the West itself. The famous obligatory university US university course on "Western civilization"- - $\mathrm{a}$ US equivalent to the Soviet course on "Marxism-Leninism"-petered out in the late 1960s, with the Western student rebellion (Allardyee 1982).

Universalist worldviews are not all unable to enlist intense identification and commitment. Hundreds of thousands have risked their jobs, their safety, and their lives fighting for socialism. Many more have risked martyrdom for their faith in universalist religions like Christianity and Islam. Anti-Communism has also recruited fervent attachment and fighting spirit. Bereft of Communist foes as well as of the glory of Western civilization liberal democratic capitalism stand culturally naked.

\section{The International Relations of Civilizations}

The strongest claim for the current importance of civilizations has been made by Huntington, a prominent scholar and an adviser of US imperial policy. First laid out in an essay in Foreign Affairs in (1993), and later expanded into book form, Huntington argued that "the principal conflicts of global politics will occur between nations and groups of different civilizations. The clash of civilizations will dominate global 
politics" (Huntington 1993, p. 22). In other words, state actions will be determined by their civilizational affinity. Huntington singled out "seven or eight major civilizations": "Western, Confucian, Japanese, Islamic, Hindu, Slavic-Orthodox, Latin American, and possibly African civilization" (1993, p. 25). In his book elaboration (1996, ch. 1) Huntington added a Buddhist civilization, while remaining ambivalent about Africa.

This is a hodge-podge of cultural formations, very different in vintage, depth, and extension, not much theoretically developed in the book version. It is meant as a map for post-Cold War US foreign policy and wars, hot and cold. As such it is not off the mark, subsuming Europe under Western, distinguishing Japan from China, marginalizing Africa. Treating Latin America as one cultural area makes geopolitical sense, although hardly a civilizational. It is less helpful to the planners of the State Department and the Pentagon by subsuming South and, in particular, Southeast Asian Islamic culture (of Indonesia and Malaysia) under one Islamic label, and Huntington acknowledges himself the East-West divide of "Slavic-Orthodox" Ukraine.

It derives its relative persuasiveness from the late twentieth century "return of God", and the surge of organized religion in most parts of the world, save Western Europe. That religious renaissance in turn goes back to the failures and defeats of the two major secular ideologies of the century, secular developmental nationalism and socialism,/communism, which also "culturalized" states, in different ways.

Huntington was a perceptive cartographer of coming wars and conflicts of the US, and he also had some good advice. He warned against the dangers of interfering in other civilizations, and added "In the emerging world of ethnic conflict and civilizational clash, Western belief in the universality of Western culture suffers three problems: it is false, it is immoral, and it is wrong" (Huntington 1996, p. 310). However, the catchy phrase "clash of civilizations" is too simple to account for the complexity of the seemingly endless wars in Afghanistan, Iraq, Syria, Yemen, Somalia, Libya, and their spread into the Sahel south of Sahara, clashes which in many ways are also intra-civilizational and old imperial geopolitics.

The escalating conflict between USA and China is probably aggravated by involving states of two very different civilizations, but it would be grossly misleading to characterize it as a clash of civilizations. It is a challenge of US socio-economic primacy and world hegemony by China and an American refusal to accept China as an equal. The challenge to an existing hegemon by a rising power is a classical phenomenon of geopolitics. A US international relations scholar (Allison 2015) is calling it "the Thucydydes Trap", after the historian/participant of the Peloponnesian War in ancient Greece between hegemonic Sparta and rising Athens, with their allies, 2400 years ago. The form of the US-China conflict and its prospects are significantly affected by the very different civilizations to which the competing states belong, but the conflict is typically geopolitical. As such, its outlook is pretty scary, World War I had roots in the German challenge to the dominating British empire, and the global widening of a European conflict into World War II was due to Japan challenging the US and US refusal to compromise.

The Markets First globalization since the 1980s stumbled on the financial crisis of 2008 , and may now be seen as overtaken by a state-driven geopolitical globalization, 
announced by Donal Trump at his inauguration in January 2017, “America First"! In this, more state-centred context, cultural experiences and outlooks, national and civilizational, are likely to increase their influence upon international relations, through their impact on the political culture of nation-states. Civilizational politics of international relations, it should be noticed though, is not reducible to conflicts and clashes. It has also inspired inter-civilizational dialogue, most ambitiously the United Nations Alliance of Civilizations initiative, an institutionalized platform for intercultural encounters and cooperation (www.unaoc.org).

\section{Civilization States}

A civilization state can be two different things, a political project of power legitimation or a cognitive tool, a scholarly concept which can enrich political understanding and knowledge. A state may be both, but that is not to be assumed, and in fact a coincidence of political rhetoric and institutional intelligibility is empirically rare. A civilization state is by definition a pre-modern state, claiming its uniqueness by its inheritance of a pre-modern civilization. Civilization states are conservative, not to say literally reactionary political projects.

The best example of political understanding being illuminated by the concept of civilization state is Japan. The pathway to political modernity by Reactive Modernization did not directly lead to a nation-state. No nation was rising and claiming sovereignty, instead a sector of the pre-modern elite seized power and set out to transform the state and society in order to meet the threats of Euro-American imperialism. Japan was not only the most successful case, it managed through creatingN.B. not simply inheriting - a political system topped by something well captured by the concept of a civilizational state. That is, a unique Japanese polity (kokutai), centred on an emperor of divine descent, in whom sovereignty resided due to his belonging to "a line of Emperors unbroken for ages eternal", as the constitution of 1890 says, a constitution presented as an "imperial gift". Eisenstadt (1996, p. 430) sums up the specificity of the Meiji Restoration well: "It was proclaimed as a renovation of an older archaic system, which in fact had never existed, and not as a revolution aiming to change the social and political order ..." At the same time, the "Restoration" was a modern opening, "knowledge shall be sought throughout the world" in the pursuit of country strength said the new regime's first major declaration, the Charter Oath of 1868 (Beasley 1990, p. 56).

Japan became a modern power, not as a nation- state but as a "national structure with the emperor at center" (kokutai), a specimen of a civilizational state. Only under US occupation and dictation of the constitution did Japan became a state of national sovereignty, and only with Japanese translations of the American draft trying to obscure the change from imperial to popular sovereignty (Dower 1999, ch. 13) By 1996, the understanding of the key concept of the Japanese civilization state had faded so much that the newspaper Asahi Shimbun found it necessary to insert an explication of kokutai (the one I used above) in an interview with a witness to the 1946 constitutional debate Dower 1999, p. 615). 
China was transformed from a dynastic to a nation-state, by the Republican revolution of 1911 and reasserted by the People's Republic of 1949. The current arguments about a Chinese civilization(al) state ${ }^{1}$ (Jacques 2009; Zhang 2012) refer to its importance as an aspect of the contemporary state and political regime. This is also an illuminating deployment of the concept, pointing to a state with a uniquely long continuous history, across its several ruptures of power, and a cultural civilization still in touch with its past 2500 years ago as a formidable source of legitimacy and resilience. The pertinence of the argument is summed up by a Singaporean observer of world affairs: "America is not competing with an anachronistic Communist party. It is competing with one of the world's oldest and strongest civilizations." (Mahbubani 2020, pp. 129-30). The strength and durability of this, rather recent, alignment between the CCP and a reinvigorated neo-Confucian civilization is an empirical question for the future. It is an interesting and important question following from the conceptualization.

In India and Russia, by contrast, the civilization state appears mainly as a political project, of controversial aims of power.

Indian civilization is large and ancient, but it has neither a long state continuity, nor a religious one, and it has less of a tradition of political philosophy than China. Its current state was established as a post-colonial nation-state, as part of a universalist anti-colonial nationalism. Few post-colonial states resembled the European model, of historical borders and cultural commonalities, but as the first postcolonial state and because of its sub-continental linguistic, religious and cultural diversity, India became more preoccupied with its new variant of a nation-state than most other states of the former Colonial Zone of Africa and Asia. The idea of India as a civilization state emerged as a way of coping with contemporary diversity while building on the pride of ancient Indian civilization. (Kumar 2002; Oommen 2004; Singh 2016) It was mainly a cultural project of identity, lacking any specific political prescriptions, and any strong pan-civilizational traditions to build on.

Much more politically important is the Hindu civilization project pushed by the current BJP government and its Prime Minister Narendra Modi. It portrays the almost millennial Muslim part of Indian civilization as an alien intrusion, and is doing its best for erasing the memory of, and for further marginalizing the remaining poor Muslim population, about 13 per cent of the total population, roughly equal to the proportion of African-Americans in USA. An exclusive Hinduist state is a quite possible political project, but whether it would be enlightening to label it a civilization state is another question (Cf, Coker 2019, p. 126ff; Macães 2020).

Vladimir Putin talks since 2012 of Russia as a "state-civilization" (gosudartstvotsivilizatsiia)) rather than as a civilization state (Linde 2016, p. 23), which seems to mean a state-centred, multi-ethnic civilization, where the Russian Orthodox Church has an important part, alongside the Russian language and Russian cultural traditions. These speeches should probably be taken as a unifying identity project for a

\footnotetext{
1 Zhang (2012, p. 47) makes a distinction between a civilization state and a civilizational state, the latter being an amalgamation of "the world's longest continuous civilization with a huge modern nation-state".
} 
disoriented post-Communist Russia hurt by the West. Civilization state implications remain unclear and uncertain.

\section{Conclusion}

As incarnations of nations, modern states are inherently cultural entities, but the meaning of the nation varies with the path of nation-state formation. Nations and nation-states of the world cannot be reduced to European examples. An analytical comparison of nations and civilizations as cultural entities yields insights into both, about their different modes of impact and their different location in time and history.

Civilizations, in plural, is a legitimate and valuable concept of cultural and ecological analysis. The abuse of it for rhetoric of exclusion and supremacy/subordination is a reason for critical scrutiny, not for conceptual abandonment. Ancient civilizations do have enduring effects, both as traces of long past experiences and as a cultural repertoire which can be played upon, for aesthetic as well as for political reasons. As such they impinge upon the political culture of contemporary states but they do not clash, movements, politicians, states, organized religions do.

All civilizations are rich depositories of knowledge, experiences, and imaginations. Bringing them to light is an invaluable contribution to human culture, particularly in an era in which modern mass culture tends to drown classical civilizational education. Investigations of civilizational influence on political cultures, and thereby on states and their international relations are not only intellectually promising. In a world increasingly governed by states and other actors not coming out of Western civilization, inter-civilizational knowledge and comparison become increasing important.

Civilization states have in the past decade become a fashionable topic. Publications about their "rise" abound. The secretary general of the Hinduist current Indian government party, BJP, has declared: "Asia will rule the world, and that changes everything because in Asia we have civilizations rather than nations."(Ram Madhav quoted by Macães 2020). The empirical record conveys a more modest picture, of intellectual constructions or political rhetoric with uncertain prospects. The only full-blown modern civilization state, the Japanese emerging from the Meiji Restoration, has faded away, mutating into a conservative nation-state. The concept opens up new insights into contemporary China, but a Sino-centric worldview would may not be much of an intellectual advance over a Western-centred view.

While ancient civilizations impinge upon contemporary states, the latter's modern history including the rise of the nation cannot be truthfully erased, and would mislead efforts to understand the current state. The imagined communities of nations and civilizations and their cultural affinities and alienations clearly have both an impact on and a propelling potential of international conflicts, but they continue to operate within a framework of universalist geopolitical conflicts of power and wealth.

Finally, it should be noticed, that there is an embryonic alternative to a politics of civilizations emerging, a planetary politics, focused on planetary and panhuman issues, on the threats of global warming, of recurrent pandemics, and of worldwide 
human inequality and inequity. It is part of the global shift going on in the world that while missionary universalism is running out of "America First", in 2020 it has been the government of the civilization(al) state of China which has given support to a planetary politics.

Open Access This article is licensed under a Creative Commons Attribution 4.0 International License, which permits use, sharing, adaptation, distribution and reproduction in any medium or format, as long as you give appropriate credit to the original author(s) and the source, provide a link to the Creative Commons licence, and indicate if changes were made. The images or other third party material in this article are included in the article's Creative Commons licence, unless indicated otherwise in a credit line to the material. If material is not included in the article's Creative Commons licence and your intended use is not permitted by statutory regulation or exceeds the permitted use, you will need to obtain permission directly from the copyright holder. To view a copy of this licence, visit http://creativecommons.org/licen ses/by/4.0/.

\section{References}

Acharya, Amitav. 2020. The myth of the "civilization state: rising powers and the cultural challenge to world order. Ethics \& International Affairs 34 (2): 139-156.

Al-Hafidh, Rabee. 2020. Rise of the civilizational state in post-nation-state Middle East, https://www. dailysabah.com/opinion/op-ed/rise-of-the-civilizational-state-in-post-nation-state-middle-east. Accessed 2 Sept 2020.

Allardyee, Gilbert. 1982. The rise and fall of the western civilization course. The American Historical Review 16 (3): 695-725.

Allison, Graham. 2015. The Thucydides Trap. https://www.hks.harvard.edu/sites/default/files/centers/ mrcbg/files/Allison\%2C\%202015.09.24\%20The\%20Atlantic\%20-\%20Thucydides\%20Trap.pdf. Accessed 9 Sept 2020.

Alvaredo, Francisco et al. (eds.) World Inequality Report 2018. https://wir2018.widworld. Accessed 25 Jan 2020.

Annino, Antonio, and Francois-Xavier. Guerra. 2003. Inventando la nación. Iberoamérica, Siglo XIX. Mexico: Fondo de Cultura Económica.

Bai, Tongdong. 2020. Against political equality. The confucian case. Princeton: Princeton University Press.

Beasley, W.G. 1990. The rise of modern Japan. New York: St. Martin's Press.

Bell, Daniel, and Wang Pei. 2020. Just hierarchy. Princeton University Press: Princeton.

Bowden, Brett. 2016. Civilization and its consequences. https://www.oxfordhandbooks.com/ view/10.1093/oxfordhb/9780199935307.001.0001/oxfordhb-9780199935307-e-30. Accessed 20 July 2020.

Braudel, Fernand. 1987. Grammaire des civilisations. Paris: Flammarion.

Coker, Christopher. 2019. The rise of the civilizational state. Cambridge: Polity.

Commager, Henry Steele. 1950. The American mind. New Haven: Yale University Press.

Dower, John. 1999. Embracing defeat. London: Penguin.

Eisenstadt, S.N. 1996. Japanese civilization. Chicago: Chicago University Press.

Fan Yi, Junjian Yi, Junsen Zhang. 2015. The great Gatsby curve in China: cross-sectional inequality and intergenerational mobility. https://abfer.org/media/abfer-events-2015/annual-conference/economictransformation-asia/the-great-gatsby-curve-in-china-cross-sectional-inequality-and-intergeneration al-mobility.pdf. Accessed 16 Sept 2020.

Fukuyama, Francis. 1992. The end of history and the last man. New York: Free Press.

Gong Honge, Andrew Leigh, Xin Meng. 2012. Intergenrational income mobility in China. Review of Income and Wealth 58(3):481-503. https://doi-org.proxy.lnu.se/10.1111/j.1475-4991.2012.00495.x. Accessed 16 Sept 2020.

Huntington, Samuel P. 1993. The clash of civilizations? Foreign Affairs 72 (3): 22-49. 
Huntington, Samuel P. 1996. The clash of civilizations and the remaking of world order. New York: Simon \& Schuster.

Jacques, Martin. 2009. When China rules the world. London: Allen Lane.

Katzenstein, Peter (ed.). 2010. Civilizations in world politics. New York: Routledge.

Kumar, Ravinder. 2002. India: a 'nation-state' or 'civilization-state'? South Asia 25 (2): 13-42.

Lepore, Jill. 2018. These truths. A history of the United States. New York: W.W. Norton.

Linde, Fabian. 2016. State Civilization: the statist core of Vladimir Putin's civilizational discourse and its implications for Russian foreign policy. Politics in Central Europe 12 (1): 1-33.

Macães, Bruno. 2020. The attack of the civilization-state. https://www.noemamag.com/the-attack-of-thecivilization-state. Accessed 2 Sept 2020.

Mahbubani, Kishore. 2020. Has China won? New York: BBS Public Affairs.

Nora, Pierre. 1988. Nation. In Dictionnaire critique de la Révolution Francaise, ed. Francois Furet and Mona Ozouf, 801-811. Paris: Flammarion.

Oommen, T.K. 2004. Futures India: society, nation-state, civilization. Futures 36 (6-7): 745-755.

Prakash, Abhinav. 2016. New paradigm for India: from nation-state to civilizational-state. https://www. swatajyamag.com/books/new-paradigm-for-india-from-nation-state-to-civilizational-state. Accessed 2 Sept 2020.

Rachman, Gideon. 2019. China, India and the rise of the "civilization state". Financial Times. March 4.

Roussinos, Aris. 2020. The irresistible rise of the civilizational state. https://unherd.com/2020/08/theirresistible-rise-of-the-civilisation-state/. Accessed 2 Sept 2020.

Schölderle, Thomas. 2011. Verfassungspatriotismus und politische Bildung. https://www.apb.tutzing.de/ download/2011. Accessed 20 Aug 2020.

Schulze, Hagen. 1994. Staat und Nation in der deutschen Geschichte. München: C.H. Beck.

Singh, Abhinav Prakash. 2016. New paradigm for India: from nation-state to civilization-state

Spengler, Oswald. 1918-22/1991. The decline of the west. Oxford: Oxford University Press.

Therborn, Göran. 1995. European modernity and beyond. London: Sage.

Therborn, Göran. 2011. The world. Cambridge: Polity.

Therborn, Göran. 2017. Cities of power. London: Verso.

Therborn, Göran. 2020. Inequality and the labyrinths of democracy. London: Verso.

Wood, Gordon S. (ed.). 1990. The rising glory of America 1760-1820. Boston: Northeastern University Press.

Zhang, Weiwei. 2012. The China wave. Rise of a civilizational state. Shanghai: World Century. 